Dr PAVEL VAVRIŠUK, asistent

Univerzitet Kazimira Velikog

Bidgošć, J. K. Hotkjeviča 30

Republika Poljska

UDK 327(497.1:438)"1945/1948"(093.2)

pawel.wawryszuk@gmail.com

originalan naučni rad

primljeno: 20. januar 2016.

prihvaćeno: 20. april 2016.

\title{
POLJSKO-JUGOSLOVENSKI ODNOSI 1945-1948.
}

APSTRAKT: Rad sadrži kratak osvrt na poljsko-jugoslovenske odnose u periodu 1945-1948. i predstavlja uvod u dublje istraživanje političke, ekonomske, kulturne i vojne saradnje između dve države posle Drugog svetskog rata, o kojoj nedostaju studije. Članak je zasnovan na arhivskom materijalu iz poljskog i jugoslovenskog ministarstva spoljnih poslova (Archiwum Ministerstwa Spraw Zagranicznych u Varšavi i Diplomatski arhiv Ministarstva spoljnih poslova $u$ Beogradu) i arhiva Komunističke partije (Archiwum Akt Nowych u Varšavi), a dopunjen je opštom literaturom, memoarima i štampom.

KLJUČNE REČI: Poljska, Jugoslavija, međunarodni odnosi, poljskojugoslovenski odnosi

Kao rezultat opštih procesa koji su se odvijali poslednjih godina Drugog svetskog rata postalo je očigledno da će posleratnu stvarnost u istočnoj srednjoj Evropi determinisati Sovjetski Savez. Ipak, ostalo je otvoreno pitanje na koji je način podrška anglosaksonskih sila pružena poljskoj ilegali, koja se borila za nezavisnost, mogla da utiče na usporavanje delatnosti komunista. ${ }^{1}$ Sasvim drugačije je izgledala situacija u Jugoslaviji u kojoj su dominantan položaj imali komunisti sa Josipom Brozom Titom na čelu i koji su se borili, ne bez uspeha, sa okupatorom, ali - možda pre svega - i sa svim snagama koje su mogle da ugroze njihovu kasniju prevlast $u$ zemlji. ${ }^{2}$ I $\mathrm{u}$ jednom i u drugom slučaju krajnji cilj je bilo osvajanje nekontrolisane i

${ }^{1}$ Alan P. Dobson i Steve Marsh, US Foreign Policy since 1945. (The Making of the Contemporary World), (London and New York: Routledge, 2001), 18, itd.

${ }^{2}$ Kao što proističe iz jedne naredbe Vrhovnog štaba komunista: „Sada [kraj 1942. i početak 1943] sve svoje snage morate usmeriti na likvidiranje četnika. To mora biti vaš glavni cilj“. Michał Jerzy Zacharias, Komunizm - federacja - nacjonalizmy. System polityczny w Jugosławii 1943-1991. Powstanie - przekształcenia - rozkład (Warszawa: Neriton, 2004), 46. 
potpune vlasti, mada metode i strategija koje su tome služile nisu bile istovetne u oba slučaja.

Sam proces preuzimanja vlasti od strane komunista u Jugoslaviji je tekao slično onima koji su se odvijali u drugim zemljama istočne srednje Evrope. Doduše, taj proces se odigrao bez „prelaznog perioda“ koji je karakterisalo privremeno tolerisanje nekomunističkih snaga. Jugoslovenski komunisti su dosta rano odlučili da monarhija nema pravo da postoji u posleratnoj stvarnosti zemlje. Uvođenje novog državnog uređenja postalo je njihov glavni cilj. Zanimljivo, ali radikalni koraci koje je preduzimala Titova ekipa i koji su vodili ka što bržoj eliminaciji opozicije nisu bili potpuno po Staljinovoj volji. On je u planovima pre svega imao postepenu izgradnju svoje uticajne zone $\mathrm{u}$ istočnoj srednjoj Evropi, i, barem privremeno, umirivanje zapadnih sila.

Za vreme neočekivane Titove posete Moskvi (23. septembar 1944) Staljin je bio suzdržan prema njegovoj politici u odnosu na kralja i izbegličku vladu, savetujući mu uzdržanost i zauzimanje stava koji omogućava taktički kompromis sa monarhistima, kao i da sačeka sa uvođenjem novog ustavnog poretka do završetka vojnih operacija i buduće mirovne konferencije. ${ }^{3}$ Tito je, i pored svega, ostao pri svome stavu o vođenju unutrašnje politike, ali je istovremeno dobio garanciju povećanja sovjetske pomoći i vojne podrške u predstojećoj ofanzivi u pravcu Beograda. Pred kraj rata, dakle, otvoreno je ostalo pitanje stepena zavisnosti od Sovjetskog Saveza i slobode u oblikovanju sopstvene spoljne politike koja je s tim povezana.

Ne zalazeći u detalje unutrašnjeg položaja obe države, još pre uspostavljanja zvaničnih diplomatskih odnosa između Poljske i Jugoslavije bilo je očigledno da će zajednički interesi prelaziti okvire pitanja utemeljivanja komunističke vlasti, mada ih je u značajnom stepenu karakterisala simbolika usmerena na potrebe unutrašnje propagande. I pored toga, stanovišta obe zemlje u najbitnijim pitanjima - granice, oslonac na Sovjetski Savez, unutrašnja politika - u velikoj meri su bila bliska. To je stvaralo pogodne uslove za izgradnju, na novoj osnovi, uzajamnih odnosa koji nisu bili opterećeni teritorijalnim sporovima nego povezani na ideološkom planu.

Prelazni period koji je nastupio u većini država istočne srednje Evrope od kraja rata do konferencije u Šklarskoj Porembi 1947, u velikoj meri iznuđen taktičkim faktorima koje su koristili tamošnji komunisti, nije postojao u Jugoslaviji. Ipak, to nije poništavalo politiku jačanja saradnje koja je omogućavala legitimizaciju i učvršćivanje uticaja komunista. Tim pre, kao što je isticao izaslanik za štampu poljske ambasade u Beogradu, dr Marjan Jakubjec: „Simpatije prema nama su postojale odavno. Pomračivao

${ }^{3}$ Više o tome: Zofia Rutyna, Jugosławia na arenie międzynarodowej 1943-1948 (Warszawa: Książka i Wiedza, 1981), 51, itd. 
ih je jedino beleg poljskog plemićkog duha, naš društveni elitizam i borba sa Rusijom. Stav poljskog naroda za vreme poslednjeg rata rasprostranio je ime Poljske u neverovatnom stepenu, a društvene promene koje su se odigrale pokazale su prosečnom Jugoslovenu da je sadašnja Poljska stvarno demokratska i da je svojina radnog naroda. [...]. Često upotrebljavan pojam „brat Poljak“ nije fraza. Postali smo bliski jedni drugima [...]. Drugi smo, posle Sovjetskog Saveza, prijatelj i saveznik“. ${ }^{4}$ Mada se može činiti da je ovo mišljenje bilo determinisano „zvaničnim optimizmom“ diplomate nižeg ranga, u njemu je sadržano zrno istine, o čemu će biti više reči u daljem tekstu.

Tokom poslednjih ratnih godina $\mathrm{u}$ okviru Poljske radničke partije (PPR), kao i među pojedinim njenim rukovodiocima, iskristalisala su se izvesna gledišta, između ostalog, bitna sa stanovišta poljsko-jugoslovenskih odnosa, koja su se odnosila na prenošenje sovjetskih uzora neposredno na poljsko tlo. Stav koji je, pored ostalih, ispoljavao Vladislav Gomulka i koji je pretpostavljao „izgradnju socijalizma“ imajući u vidu lokalne uslove ${ }^{5}$ ostavio je pečat na poljsko-jugoslovenskim odnosima posle Staljinove, a kasnije i smrti Boleslava Bjeruta. Kada se Poljska ujedinjena radnička partija našla pred neminovnim izborom novih vlasti jugoslovensko Ministarstvo spoljnih poslova je, bez svake sumnje, navodilo Gomulku kao osobu koja će odlučivati o pravcu delovanja partije, ne krijući izvesnu simpatiju i nade vezane za njega.

Poljsko-jugoslovenski odnosi su zvanično uspostavljeni 30. marta $1945,{ }^{6}$ a 12. jula 1945. Borba je objavila vest o dolasku u Beograd Jana

4 Arhiv Ministarstva spoljnih poslova (Archiwum Ministerstwa Spraw Zagranicznych), (AMSZ), fond Odeljenje za štampu i informaciju, (z)espół 21, (w)iązka 51, (t)eczka 737, Raport prasowy Nr 9, pismo br. 5621 od 8. 4. 1946. Wydział Prasowy, k. 88-89.

${ }^{5}$ Više o tome: Krystyna Kersten, Narodziny systemu władzy. Polska 1943-1948, (Poznań: Kantor Wydawniczy SAWW, 1990), 54, itd. Kao što kasnije, analizirajući reči Gomulke, Bjeruta i Zambrovskog u vezi sa nepostojanjem „diktature proletarijata“ u Poljskoj, primećuje Kersten: „To isto su uostalom ponavljale komunističke vođe u Čehoslovačkoj, u Mađarskoj i u Bugarskoj“ - ali ne i u Jugoslaviji. Ibid., 156.

6 Na zasedanju Privremene vlade Republike Poljske (Tymczasowy Rząd Rzeczypospolitej Polskiej - TRRP) u odgovoru na akt kojim je priznat od strane svog ekvivalenta u Jugoslaviji (premijer i ministar narodne odbrane Demokratske Federativne Jugoslavije je bio Tito). Prethodnik TRRP, Poljski odbor narodnog oslobođenja (Polski Komitet Wyzwolenia Narodowego - PKWN) bio je priznat jedino od strane SSSR-a. Sada mu se, osim Čehoslovačke, priključila i Jugoslavija. Akreditovani su i prvi ambasadori - u Varšavi Božidar Ljumović. Jugoslovenski MSP je budno pratio pitanje priznavanja (ili nepriznavanja) TRJN (Tymczasowy Rząd Jedności Narodovej - Privremena vlada narodnog jedinstva); up. Diplomatski arhiv Ministarstva spoljnih poslova Republike Srbije (DA MSP), Politička arhiva (PA), Poljska, 1945, fascikla (fasc.) 25, signatura (sign.) 2857. Priznanje Poljske vlade

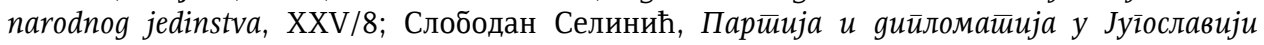
1945-1952 (Београд: Институт за новију историју Србије, 2013), 56. 
Karola Vendea, prvog ambasadora, zajedno sa osobljem predstavništva. ${ }^{7}$ Iz perspektive 1945. godine Poljska se jugoslovenskim komunistima činila važnim saveznikom, dok je politički karakter poljsko-jugoslovenskih odnosa $\mathrm{u}$ velikoj meri diktirala potreba da se osigura bezbednost posle rata. Jedan od elemenata u realizaciji tog cilja bio je sistem bilateralnih saveza država regije sa centralnim sedištem u Moskvi. Ratifikaciju ugovora između Poljske i SSSR-a prokomentarisala je i $B o r b a^{8}$ ističući demokratski karakter tadašnje poljske države. Uzimajući u obzir lokalne uslove, jezik propagande je bio istovetan sa onim korišćenim u unutrašnje svrhe. Nekoliko dana kasnije, 22. jula, časopis Duga u članku „Grad junak i mučenik“ kritikuje Varšavski ustanak: „Da tragedija i razaranje Varšave budu potpuni, zbog huškanja poljske izbegličke londonske klike dolazi do nesrećnog i avanturističkog ustanka gen. Bora-Komorovskog 1. avgusta 1944. godine. Ustanak je izbio u najnepovoljnijem trenu, bez sporazuma sa saveznicima i usklađivanja sa njihovim ratnim operacijama. Rezultat toga je bilo 300.000 žrtava, među njima i 120.000 vojnika [?]. Grad je bio užasno razoren bombardovanjem iz vazduha i sa zemlje, a sve što je još preostalo Nemci su kasnije zapalili i digli u vazduh za vreme nešto kasnijeg napredovanja Crvene i Prve poljske armije“. 9

U jednom od izveštaja koje je pripremio prilikom VIII zasedanja Zemaljskog narodnog saveta, jugoslovenski ambasador Ljumović je potvrdio kurs Varšave ka sklapanju antinemačkog saveza slovenskih država kao i spremnost da se zaključi trgovinski sporazum između Poljske i Jugoslavije. U razgovorima, u kojima je učestvovao i Vende, utvrđeno je da će mogućnosti i interesi obe zemlje biti analizirani u potrebnom stepenu. ${ }^{10} \mathrm{Za}$ vreme

${ }^{7}$ U tekstu je navedeno osoblje ambasade: I sekretar Zigmunt Sten-Stoberski, II sekretar Andžej Konarek, Marjan Jakubjec kao izaslanik za štampu i konzularni izaslanik Kažimiež Krikovski. Akreditivna pisma su predana 14. jula. AMSZ, fond Kabinet Ministra, z. 15, w. 112, t. 11, Raport prasowy nr 1 od 11 do 14 lipca 1945 r., 2. Vredi naglasiti da je u tom periodu Poljska imala tek deset ambasada. Generalno, njen rad u početnom periodu je bio veoma otežan, ako uzmemo u obzir bar saobraćajne probleme, ali i stvaranje od osnova Ministarstva spoljnih poslova u Varšavi. Više o tome: Włodzimierz Borodziej, Od Poczdamu do Szklarskiej Poręby. Polska w stosunkach międzynarodowych 1945-1947 (London: Aneks, 1990), 77, itd. Slične probleme je imalo jugoslovensko predstavništvo u Varšavi, npr. u prevođenju tekstova za agenciju Tanjug zbog čega su oni često objavljivani sa priličnim zakašnjenjem. Up. DA MSP, PA, Poljska, 1945, fasc. 25, dosije 4, sign. 3057, VIII zasedanje Zemaljskog narodnog vijeća Poljske, broj 126, 26. 7. 1945, 4 (XXV/14).

${ }^{8}$ Borba, 8. 5. 1945.

${ }^{9}$ Duga, 22. 7. 1945. Jugoslovenska štampa je opisivala Varšavski ustanak prema opšteprihvaćenoj šemi, predstavljajući objektivne teškoće Crvene armije u oslobađanju dela Varšave na levoj obali Visle.

${ }^{10}$ DA MSP, PA, Poljska, 1945, fasc. 25, dosije 4, sign. 3057, VIII zasedanje Zemaljskog..., 2 (XXV/12). Tekst sporazuma: Archiwum Akt Nowych (Arhiv novih dokumenata) 
Trećeg zasedanja AVNOJ-a ${ }^{11}$ kratak, jedva polučasovni ekspoze održao je Tito koji nije govorio samo o odnosima sa Poljskom, ali je to učinio odmah posle izlaganja odnosa sa SSSR-om i pre pitanja vezanih za Čehoslovačku, SAD, Veliku Britaniju ili Francusku. Deo „poljskog“ govora delegati su prihvatili gromkim aplauzom: „Ako je Poljska u pitanju, Jugoslavija je bila jedna od prvih država koja je pozdravila privremenu, demokratsku vladu Poljske i sklopila sa njom normalne diplomatske odnose. Taj korak naše vlade je sa radošću primio naš narod koji želi da živi u najbližim odnosima sa bratskim poljskim narodom čija je sudbina bila slična sudbini našeg naroda“. ${ }^{12}$ Kada je tokom septembra u Jugoslaviju iz Poljske stiglo 112 vagona uglja (zvanično to je bila pomoć jugoslovenskom društvu pred nadolazeću zimu), Tito je bio „duboko ganut odlukom Vaše Vlade [...]. Taj dar nove demokratske Poljske [...] je još jedno od bratskih osećanja poljskog naroda prema našim narodima". ${ }^{13}$

Tokom druge polovine 1945. poljska ambasada u Beogradu je $u$ okviru poljsko-jugoslovenskih odnosa na prvo mesto stavila pitanje pripreme trgovinskog ugovora, sporazuma o kulturi, kao i formalnog saveza. U julu 1945. sa maršalom Rolom-Žimjerskim razgovarao je vojni izaslanik ambasade Jugoslavije, pukovnik Beočić - tema susreta je bila saradnja u oblasti propagande. Žimjerski je uveravao u „najviše priznanje“ za ustanike i sa „entuzijazmom" se odnosio prema perspektivama dalje saradnje. Jugoslovenski MSP i Generalštab Jugoslovenske armije (Političko odeljenje) celu stvar su tretirali veoma ozbiljno, poveravajući Beočiću da pripremi informativnu kampanju o uspesima jugoslovenskih partizana za vreme oslobodilačke borbe. „Stvorićemo literaturu koja će opisivati evoluciju našeg partizanskog pokreta od malih odreda do armije", ${ }^{14}$ pisao je Beočić. Trećeg avgusta iste godine, $u$ pismu jednom od načelnika jugoslovenskog MSP, Joži Brileju, diplomata nižeg ranga, piše „o velikoj propagandnoj akciji [na temu] našeg partizanskog odreda. U Varšavi je organizovana izložba našeg Generalštaba, došlo je do razmene novinara“. ${ }^{15}$ Atmosferu je opisivao kao „veo-

(AAN), fond Inostrano odeljenje Centralnog komiteta Poljske radničke partije (WZ KC PPR; od decembra 1948. KC PZPR), 295, XI-400, k. 111.

${ }^{11}$ Treće zasedanje Antifašističkog veća narodnog oslobođenja Jugoslavije trajalo je između 7-11. avgusta 1945, kada je doneta odluka o njegovom pretvaranju u Parlament, odnosno u Narodnu skupštinu.

${ }_{12}$ AMSZ, z. 21, w. 51, t. 737, k. 6, Raport prasowy nr 3 od 26-27. 8. 45, Belgrad dn. 21. 8. 1945.

${ }^{13}$ Ibid., Raport prasowy nr 4 od 22. 9. - 2. 10. 1945, 3. 10. 1945, 1-2. (Videti i: Borba i Politika, 24. 9. 1945).

${ }^{14}$ DA MSP, PA, Poljska, 1945, fasc. 25, dosije 1, sign. 4137, Генералшйабу Јуі̄ословенске армије, Полииичиом одељењу, XXV/2.

${ }^{15}$ DA MSP, PA, Poljska, 1945, fasc. 25, dosije 22, sign. 2220, Pismo od 3. 6. 1945, $\mathrm{XXV} / 437$. 
ma prijateljsku“, mada je ukazivao i na loše životne uslove (pre svega na probleme sa snabdevanjem, ali i sa prijemom radio stanica).

Najvažniji događaj u poljsko-jugoslovenskim odnosima tokom 1946. bila je Titova poseta Poljskoj na proleće te godine, mada zvaničnom dočeku vođe KPJ od strane diplomatskog kora nisu prisustvovali američki i britanski ambasador. Na večeri koju je priredio Bjerut bio je prisutan ambasador SSSR Viktor Lebjedjev, ${ }^{16}$ što je na simboličan način prikazivalo odnose. ${ }^{17}$ Ipak, večera je pružila priliku da se potpiše ugovor o kulturnoj saradnji 16 . marta 1946 (potpisali su ga Leon Kručkovski, zamenik ministra kulture i Vladislav Ribnikar) i, pre svega, ugovor od suštinskog značaja - o uzajamnoj pomoći i prijateljstvu koji su potpisali Tito i Edvard Osubka-Moravski. ${ }^{18}$ Kontroverznije je bilo (sa današnje tačke gledišta) dodeljivanje Titu ordena Virtuti Militari prvog stepena (takođe 18. marta). ${ }^{19}$ Nije izostala ni verbalna podrška jugoslovenskim aspiracijama prema Trstu ${ }^{20}$ - za vreme parade $u$ čast gosta mogli su se videti transparenti „Trst Jugoslaviji“, a Ljumović je podvlačio da Tita nije srdačno primila samo poljska vlada već i narod. ${ }^{21}$

Obe strane su sa velikom revnošću pristupile pitanju pripremane mirovne konferencije sa Nemačkom i njenim saveznicima, kao i sa njom povezanim osnovnim problemom posleratnih granica. Sa sigurnošću se

${ }^{16}$ Bio je i savetnik predstavništva SSSR u Jugoslaviji, a u završnom periodu rata ambasador pri izbegličkoj vladi Jugoslavije.

${ }^{17}$ Ne treba se čuditi ponašanju britanske i američke diplomatije. Druga polovina 1945. protekla je u Jugoslaviji u znaku borbe, bez presedana, komunista sa celokupnom opozicijom, stvarnom ili potencijalnom. Drastično su ograničene mogućnosti rada nekomunističkih članova vlade i faktički je poništena njihova šansa da sačuvaju uticaj u zemlji. Up. M. J. Zacharias, Komunizm - federacja..., 74, itd. Ipak, 17. marta francuski ambasador je za vreme zvaničnog ručka nazdravio „francusko-jugoslovenskom prijateljstvu“. DA MSP, PA, Poljska, 1946, fasc. 72, dosije 6, sign. 3201, izveštaj od 20. 3. 1946, LXXII/85.

18 Više o okolnostima i sadržaju ugovora: „Ugovor o prijateljstvu i uzajamnoj pomoći izmedju Federativne Narodne Republike Jugoslavije i Narodne Republike Poljske“, u: Dokumenti 1948, urednik Vladimir Dedijer, t. 1, (Beograd: Rad, 1980), 93-95; Włodzimierz T. Kowalski, Polityka zagraniczna RP 1944-1947, (Warszawa: Książka i Wiedza, 1971), 73, itd.; Justyna Zając i Ryszard Zięba, Polska w stosunkach międzynarodowych 19451989 (Toruń: Wydawnictwo Adam Marszałek, 2005), 97-98. Trgovinski sporazum je potpisan 18. januara 1946.

${ }^{19}$ Najviši jugoslovenski ordeni dodeljeni su poljskim diplomatama u junu 1946. Žimovski i Vende su odlikovani Ordenom zasluga za narod I reda; ukupno, jugoslovenske ordene je dobilo desetak osoba iz ambasade i poljskog MSP.

${ }^{20}$ Jugoslavija je pretendovala na taj lučki grad na teret Italije i u tome je imala sovjetsku podršku. Ta država je podržavala, u osnovi, jugoslovenski stav, mada su ponudu za rešavanje spornog pitanja podnele sve velike sile - SAD, Velika Britanija, Francuska i SSSR. Up. Z. Rutyna, op. cit., 249-260. Na kraju, pitanje Trsta je bio argument u rukama Jugoslavije, posebno posle sukoba KPJ (SKJ) sa partijama Kominforma.

${ }^{21}$ DA MSP, PA, Poljska, 1946, fasc. 72, dosije 6, sign. 3201, izveštaj od 20. 3. 1946, LXXII/85. 
može tvrditi da je to bila jedna od najvažnijih sprega koja je povezivala interese obe zemlje. Za akciju "priprema mira“ (kako su taj proces nazivali činovnici poljske ambasade) sa jugoslovenske strane je bio odgovoran Edvard Kardelj. Uopšte uzevši, jugoslovenske pripreme su visoko ocenjivane, profesionalno i s priznanjem. Ambasada u Beogradu je u priličnoj meri bila upoznata sa detaljima jugoslovenske strategije - često su znali tačne datume konkretnih koraka druge strane, kao i organizacionu šemu. Hijerarhija zadataka je bila sledeća: teritorijalna pitanja; problemi odštete i restitucije, vojna pitanja. Osnovne faze rada su bile izrada glavnih tačaka, sa gledišta dotične zemlje: projekat mirovnog sporazuma sa Nemačkom, podnošenje memoranduma o budućnosti Koruške, upućenog međunarodnom javnom mnjenju, kao i široko shvaćena propaganda. ${ }^{22}$

Ništa manje važno bilo je kadrovsko pitanje. Osim za pouzdane političke delatnike, među kojima možemo navesti Jožu Vilfana, ${ }^{23}$ generalnog sekretara misije, istovremeno $u$ rangu opunomoćenog ministra u jugoslovenskom MIP-u, našlo se mesto i za "ne nužno politički proverene“ (kako je tvrdio Vende) stručnjake: dvojicu profesora, kartografe, lokalne žitelje (iz Koruške) koji tamo vode partizanski rat. Vende je izrazito naglašavao profesionalizam prevodioca, ,[...] prvorazredni, tako da je u toku od nekoliko sati ili jedne noći moguće bilo pripremiti osnovne govore, odgovore i sl." ${ }^{44}$

Razvojem strukture delegacije stvorene su potkomisije koje su se koncentrisale na pojedina pitanja (istorijska, geografska i druga). Njihovi članovi su razradili i argumentovali pojedine teze, ali su pripremali i opšte mogućnosti odbrane tih teza; analizirani su mogući odgovori drugih strana i pripremane su razne varijante njihovog potkopavanja. ${ }^{25}$ Jugoslovenska diplomatija je pretpostavljala sveobuhvatnu saradnju obeju strana, posebno u pitanju granica. I pored toga, ispoljila se indolencija poljske strane (ostaje otvoreno pitanje da li je bila namerna ili objektivna). Za ilustraciju može da posluži šifrovani telegram Zigmunta Stena-Stoberskog u kojem je Vilfan morao da „ponavlja“ molbu da mu se dostave materijali o Povraćenim zemljama, kao i o „nama [tj. Poljskoj] neprijateljskoj argumentaciji“. Štaviše, Vilfan je stigao u London 14. januara, a kurir sa pomenutim materijalima je otputovao iz Varšave tek sledećeg dana. Slučaj izgleda još čudnije ako se u obzir uzme najviši prioritet pitanja posleratnih granica obe države. Poljska strana, osim verbalnog podržavanja Jugoslavije po pitanju Trsta, nije raspo-

22 AAN, WZ KC PPR, 295/XX-65, Korespondencja pomiędzy wiceministrem Leszczyńskim a ambasadorem Wende, k. 7.

${ }^{23} \mathrm{U}$ poljskim dokumentima njegovo prezime je zapisano kao „Wilfan“.

${ }^{24}$ Ibid. U vremenu neposredno posle rata cela diplomatija je, a ne samo poljska ambasada u Beogradu, patila od nedostatka iskusnih i profesionalnih prevodilaca, kao i stručnjaka iz drugih oblasti.

${ }^{25}$ Ibid. 
lagala gotovo nikakvim sopstvenim analizama i materijalima, što su Jugosloveni uočili. Navodno, za vreme Pariske konferencije „samo je [Juzef] Vinjevič mogao, i to samo zahvaljujući poznavanju nacionalnog pitanja $u$ Gdanjsku, po principu analogije, znalački da nastupa bez pomoći jugoslovenskog materijala u vezi sa Trstom. Svi ostali Poljaci su koristili njihove [jugoslovenske] materijale“ ${ }^{26}$ Verovatno zbog nedostatka materijala i meritorne pripreme poljska diplomatija nije pokretala pitanje Koruške, o čemu je na "delikatan“ način činovnike ambasade Poljske u Beogradu ispitivao tamošnji MIP. Zigmunt Sten-Stoberski je morao okolišno odgovarati da „očigledno nisu imali do sada prilike i slično.“27 Istovremeno, jugoslovenska diplomatija je pitanje poljske granice tretirala kao „definitivno“. Pri tome je uveravala u svoju potpunu podršku po tom pitanju, iznoseći mišljenje da problem poljsko-nemačke granice na Lužičkoj Nisi i Odri uopšte nije potrebno pokretati na Mirovnoj konferenciji, pošto su u tom pogledu dovoljne odluke „velike trojke" u Potsdamu. ${ }^{28}$

Jugoslovenska diplomatija je kritikovala Poljsku i zbog preterano suzdržanog stava prema svojim teritorijalnim zahtevima u Koruškoj. Poljska politika se pokazala „kao preterano hladna za saveznika po pitanju Slovenske Koruške. Niko od poljskih političara nije rekao nekoliko jasnih reči da smatra [jugoslovenski] stav za ispravan, ne govoreći o nekom većem nastupu“, pisao je Sten-Stoberski. Jugoslovenska strana se zbog takvog obrta osećala „pomalo uvređena“. ${ }^{29}$ To se nalazilo u opoziciji sa potpunom podrškom, ne samo verbalnom, koju je jugoslovenska diplomatija pružala po pitanju poljske zapadne granice.

U kontekstu situacije u Jugoslaviji prioritetno pitanje u početnom periodu rada poljske ambasade bili su „izbori“ u Jugoslaviji zakazani za 11. novembar 1945. Van svake sumnje, poljska diplomatija je tom događaju pripisivala odgovarajući značaj, barem verbalno: „Jugoslavija prolazi kroz najintenzivniji period svog političkog života od oslobođenja" - pisano je. „Oslobađana je energija koju vlasti pažljivo prikupljaju, a koja treba da im osigura, preko vešto izvedenog 'glasanja', odgovarajuću poziciju u budućnosti“ ${ }^{30}$ Manje od dve nedelje pre planiranih „izbora“ iz izveštaja ambasade u Beogradu saznajemo da su „Za tu akc[iju] mobilisane sve raspoložive ćelije velikog partijskog, društvenog i vojnog aparata kojima vlada raspolaže neposredno ili posredno". Izveštač je predstavljao korake koji su stremili ka

${ }^{26}$ Ibid,. 8.

${ }^{27}$ Ibid. Raport specjalny „Przygotowanie pokoju“, nr 20/tjn/6, 4. 2. 1947, 14.

28 Ibid., odgovor MSP FNRJ na notu Ambasade RP u Beogradu br. 20/4/2, 8. 1. 1947. u vezi sa saradnjom Vlade RP $i$ Vlade FNR Jugoslavije za vreme mirovne konferencije sa Nemačkom i Austrijom, br. 130/47, 19-19a.

${ }^{29}$ Ibid., Raport specjalny - „przygotowanie pokoju“, br. 20/tjn/7, 17. 2. 1947, 29.

${ }^{30}$ AMSZ, z. 21, w. 51, t. 737, Raport prasowy nr 4 od 22 IX-2 X 1945 r., 3. 10. 1945, 3. 
preuzimanju pune kontrole nad „izborima“ od strane vlasti kao opravdane, pošto su „sve ostale političke i vojne grupacije /a barem njihove vođe/, posredno ili neposredno, bile u kontaktu sa okupatorima“. Kao, donekle, posledica takvog rezonovanja „to stanje stvari je sada ovlašćivalo vladu da izvrši red organizacionih i zakonodavnih regulacija [...] koje na izvrstan način omogućuju savlađivanje reakcionarne opozicije". ${ }^{31}$ To nije bila samo konstatacija činjenica koje su postojale pre „glasanja“ u Jugoslaviji - nego praktično lekcija na koji način se mogu uspešno održati „izbori“ u Poljskoj. U izveštaju se dalje navodi: „Ta akcija, osim propagandnog i moralnog akcenta, za Narodni front [ranije nazivan Jedinstveni narodnooslobodilački front Jugoslavije] poseduje prvorazredni, čisto izborno-aritmetički značaj za dosta značajan procenat glasača koji se regrutuju iz slojeva nenaklonjenih novim strujama u Jugoslaviji - kao prvo, a priori smanjuje broj pristalica opozicije, a istovremeno automatski povećava opštu izbornu frekvenciju, a usled postojanja jedine izborne liste - borba će se voditi jedino za frekvenciju“. ${ }^{32}$ Izaslanik za štampu ambasade u Beogradu je potvrđivao da „[...] Srbi [?] podvlače da neće to biti samo vatrena proba za režim [...]. Rešenje će doneti izborna ordinacija i zakon o načinu podnošenja kandidatura, koju u napetosti očekuju“. ${ }^{33}$

Poljski diplomati (barem na tadašnjoj etapi) nisu poznavali razmere pomenute pojave, ali su je obeležavali kao "masovnu“. Ukazivano i na praktično onemogućivanje glasanja nevažećim listićima zbog nužnosti ubacivanja „izbornog listića u kutiju kada bi se glasač našao u izbornom lokalu“, što je uostalom bilo skoro potpuno sigurno uzevši u obzir "takav ili drugi“ pritisak „propagandne akcije“. ${ }^{34}$ Sama „izborna kampanja“" se odvijala uglavnom oko unutrašnjih pitanja (međunarodna pitanja su se ograničavala na tvrdnje o bratstvu sa Sovjetskim Savezom i prijateljstvu sa Zapadom; saradnja sa zemljama nesusedima je izostavljana). Iz izveštaja ambasade proističe još jedan aspekt: velika pažnja je bila posvećena organizaciji „izbora“ za vreme ekonomske krize koja se manifestovala galopirajućom inflacijom (100-150\% mesečno), a uz to i restriktivnoj politici komunista. Lek za to je trebalo da bude zabrana prodaje poljoprivrednih proizvoda iznad propisanih cena, što je dovelo do toga da je „seljak faktično štrajkovao i gradske pijace su doslovno bile prazne“, nedostajali su osnovni prehrambeni proizvodi. ${ }^{35}$ U ovom izveštaju, osim stručnog karaktera koji se vidi bar u nedostatku

${ }^{31}$ AMSZ, z. 15, w. 10, t. 109, „Informacja Placówek“, nr 2/1945, 29. 11. 1945, (ściśle tajne), 13.

32 Ibid.

${ }^{33}$ AMSZ, z. 21, w. 51. t. 737, Raport prasowy nr 2 od 15-24 VII 1945 r., 24. 7. 1945 , 3.

${ }^{34}$ AMSZ, z. 15, w. 10, t. 109, „Informacja Placówek“, nr 2/1945, 29. 11. 1945 , (ściśle tajne), 13.

${ }^{35}$ Ibid., 14. 
ideološki obojenih umetaka, realistički je opisan stav opozicionih grupa. I pored atentata koje su u Beogradu izvele snage povezane (prema mišljenju poljske ambasade) sa Mihailovićem, ocena situacije u Jugoslaviji je bila jednoznačna: „Generalno optimistička ocena razvoja političkih događaja od strane zvaničnih činilaca je u velikom stepenu opravdana“. Takođe, i pored činjenice da je u nekim krajevima Jugoslavije još trajao oružani otpor protiv komunista, a „reakcija“ je pod kontrolom držala „cele opštine“, „pojačana delatnost opozicije, izazvana aktuelnom političkom borbom, ne može da računa na ikakve realne efekte“". ${ }^{36}$

Rezultate „izbora“ ipak ništa nije moglo da poljulja. Jakubjec je izvestio: „U svim mestima omladina je pomagala starim i bolesnim da dođu na glasanje. Po one koji nisu mogli doći poslata su kola“. Zatim „u svim mestima su izabrani samo kandidati JNOF-a, što je najbolji dokaz da je u Vojvodini, i pored reakciono-šovinističke propagande, pobedilo bratstvo i jedinstvo naroda“, ${ }^{37}$ preneo je pisanje Borbe. Tito je, navodno, bio „prijatno iznenađen“ što su „izbori ispali izvanredno“. Bez sumnje, iskustvo jugoslovenskog "glasanja“ donosilo je dragocene smernice koje su u budućnosti mogle biti iskorišćene u Poljskoj, svakako uzimajući u obzir drugačiju političku situaciju nad Vislom. To je zvanično izjavio ambasador Ljumović, jednostavnim rečima opisujući situaciju krajem septembra 1945. u Poljskoj. Odgovarajući na jedno od pitanja za vreme konferencije koja se održavala u zgradi jugoslovenske ambasade, rekao je da „odnos partijskih snaga u Jugoslaviji nije takav kao u Poljskoj. U Narodnom frontu, osim 32 tačke, niko ne ističe 33. pitanje. To je platforma svih stranaka“. ${ }^{38}$

Zapostavljanje predstavništva u Beogradu od strane poljskog MIP-a, ali i relativno malo interesovanje za jugoslovenska pitanja u Poljskoj bili su povod nezadovoljstva druge strane. Prema mišljenju ambasadora Ljumovića, koje je izneo u razgovoru sa ministrom informacija i propagande Stefanom Matuševskim, poljska štampa je premalo mesta posvećivala makar pitanju Trsta, često prenoseći jedino tekstove zapadne štampe. Takođe, nije tako aktivno kritikovala „monarho-fašistički teror u Grčkoj“ ili situaciju u

${ }^{36}$ Ibid., 15. Za vreme njihovog održavanja primenjen je masovni teror; u poređenju sa OZN-om Gestapo je nazvan „blagom institucijom“. Više o izborima: Michał Jerzy Zacharias, „System stalinowski w Jugosławii 1944-1949“, Kwartalnik Historyczny, nr 3, (1992), 84-86.

${ }^{37}$ AMSZ, z. 21, w. 51, t. 737, Raport prasowy nr 2 od 15-24 VII 1945 r., 24. 6. 1945, 3.

${ }^{38}$ DA MSP, PA, Poljska, 1945, fasc. 25, dosije 22, sign. 5135, Stenografske beleške konferencije za štampu u jugoslovenskoj ambasadi 28. IX 1945, 9 (XXV/564). Konferencija za štampu je bila posledica ranijeg razgovora Ljumovića sa Matuševskim, a tom prilikom je pripremljena lista pitanja koja će biti postavljena ambasadoru (videti sledeću napomenu). 
frankističkoj Španiji, premalo je vremena na radiju posvećivano jugoslovenskim pitanjima i problemima. To je posledica „opreza“ ministarstva i izbegavanja da se reakciji i inostranim faktorima pruže povodi za napadanje „naše zajedničke stvari“, odgovorio je Matuševski. Dalje se razmatrala Ljumovićeva izjava o tome da se „demokratija u Poljskoj i Jugoslaviji razlikuje“: jugoslovenska je bliža sovjetskoj, a poljska zapadnoj. Matuševski je uveravao ambasadora da će po pitanju Trsta, „kao i u drugim pitanjima“, štampa pokazati veće angažovanje. ${ }^{39} \mathrm{U}$ razgovoru se postavilo pitanje posete Josipa Broza Tita Poljskoj i interesovanja koje u vezi sa tim ispoljava poljska strana, mada Ljumović u toj fazi još nije imao jasne instrukcije o detaljima posete.

Zanemarivanje jugoslovenske problematike potvrdio je Jan Karol Vende izveštavajući septembra 1946. Varšavu da „kada su u Jugoslaviji dobijene izvesne mogućnosti kulturne i informativne penetracije, kao i pozicija koja nije uspela da se negde drugde dobije, ne čini se ništa da bi se te pozicije zadržale. Svestan sam da Varšava dosta bagateliše izvesne radnje Ambasade u Beogradu [...]. Činjenica je ipak da neki odgovorni radnici MIP stavljaju do znanja 'šta je tamo Beograd...'. Istovremeno Česi su, organizujući po ugledu na našu ambasadu informativno-propagandni centar, dovezli vagon informativnog materijala. Mi - preziremo Beograd...". Vidljiva je bila rezignacija Vendea - o poljskom informativnom centru je nastavljao: „U svakom slučaju dalje tako ne može biti. Ili će informativni centar biti živa institucija, ili baraku treba zatvoriti. Šteta truda, troškova i mojih živaca“" ${ }^{40}$ To mišljenje je simboličan zaključak o mestu koje je Jugoslavija zauzimala u poljskoj spoljnoj politici odmah posle završetka Drugog svetskog rata, i pored čestog označavanja poljsko-jugoslovenskih odnosa kao srdačnih, prijateljskih, bratskih itd. U prvom delu prelaznog perioda pojavile su se pukotine u uzajamnim odnosima. Takva situacija ne može da čudi kada se $u$ obzir uzme, prvo, zamršena situacija u Poljskoj, a drugo, nesrazmerno komplikovaniji međunarodni položaj i donekle različiti prioriteti spoljne politike obe države, kada bi se posmatrali njeni detalji.

$\mathrm{Na}$ jugoslovenskoj strani su takođe postojale izvesne predrasude koje su proisticale iz navedenih razlika. Poljska je zvanično nazivana „drugim po redu, posle Sovjetskog Saveza, prijateljem i saveznikom“, dok nezvanično rešenja koje je primenila PPR nisu nailazila na priznanje među jugoslovenskim komunistima raznih nivoa. Suočeni sa napretkom staljinizacije zemlje, brojni partijski drugovi nisu mogli da shvate zašto u Poljskoj

${ }^{39}$ DA MSP, PA, Poljska, 1946, fasc. 72, dosije 5, sign. 3512, Posjeta Ministru informacija g. Matuševskom, pov. br. 49, 22. 9. 1945, 1-2 (LXXII/61-62). (Izveštaj je zbog nepoznatih razloga u jugoslovenskom MSP zaveden tek 29. 3. 1946).

${ }^{40}$ AMSZ, z. 21, w. 51, t. 736, Sprawa punktu informacyjnego, 18. 9. 1946 (pristiglo 23. 9. 1946), 2330/46 $\mathrm{Tj}$. 
još uvek funkcioniše višepartijski sistem. Prema Marjanu Jakubjecu, „prosečni državljanin se čudi zašto na našoj zastavi nemamo crvenu zvezdu“. U književnim redakcijama poljski materijali su bili ignorisani, pošto „su [tamo] ljudi koji bi to smatrali za povlačenje sa zauzetih ideoloških pozicija“. „Posle povratka Maršala Tita iz Varšave čuo sam za vreme mitinga razgovor viših jugoslovenskih oficira koji su ismejavali poljske ordene u obliku krsta. I ta predrasuda ne pomaže našoj propagandi“ “. ${ }^{41}$

Dešavalo se da se „u levičarskim i partijskim krugovima koji su imali lične kontakte sa ljudima iz Sovjetskog Saveza ${ }^{42}$ šire glasine da su poljske mase u najvećem stepenu antiruske i antisovjetske". Zato su te osobe smatrale neiskrenom delatnost poljske propagande i potkopavale je, a "Poljaci nisu prestali da budu reakcionari i da poriču slovensku solidarnost". Takve tvrdnje su u nomenklaturi komunista iz vremena tik posle rata bile optužbe velikog kalibra koje su potkopavale glavni dogmat koji je u Jugoslaviji još obavezivao: prijateljstvo sa SSSR-om. Te osobe iz „levičarskih krugova“ išle su u svojim shvatanjima još dalje: „Sa teškoćama smo razbijali predrasude koje su se zasnivale na vulgarnoj primitivnoj veri da je nemoguće biti prijatelj ruskog i poljskog naroda istovremeno i da akt prijateljstva prema Poljskoj može udaljiti i potkopati prijateljstvo prema SSSR [podvukao P. V.]. ${ }^{43}$ Jakubjec je kao primer naveo Radovana Lalića, sekretara Slovenskog odbora u Beogradu, ali i stručnjaka KPJ za slovenska pitanja, koji je $u$ više navrata sabotirao propoljske publikacije u beogradskoj štampi. ${ }^{44}$ Jugoslovenska strana nije htela da prihvati gledišta iznošena na stranicama poljskih književno-društvenih časopisa gde su bili prisutni „liberalizam i akademizam" sporova, u poređenju sa situacijom koja je vladala u Jugoslaviji.

Deo delatnika se, obrazlažući navedene sumnje, pozivao na „predmet generala Andersa“. Marjan Jakubjec u izveštaju navodi da je „osetio hlađenje propoljskog raspoloženja" za vreme službenog puta u Hrvatsku i Sloveniju. Lokalni funkcioneri su izražavali sledeće mišljenje: „Anders je Poljak, okupio je oko sebe 100.000 Poljaka. Kakav je, prema tome, poljski narod?". Štaviše, činjenica koja nije pozitivno uticala na viđenje Poljske bili su sentimenti koje je među delom članova KPJ uživala Čehoslovačka. Odnosilo se to na one koji su pre rata studirali u toj zemlji da bi kasnije zauzeli visoke državne položaje u Jugoslaviji. Prema Jakubjecu, ti ljudi su naučili

\footnotetext{
${ }^{43}$ Ibid

${ }^{44}$ Sam je bio publicista Borbe za koju je napisao nekoliko „iznuđenih“ (šta god to značilo) članaka o Poljskoj.
}

Saveza.

${ }^{41}$ Ibid., Raport prasowy Nr 9, br. 5621, 8 IV 1946 r., 88-89.

${ }^{42}$ Nije isključeno da su upravo to mišljenje imali pojedini zvaničnici Sovjetskog 
češki jezik, sklopili poznanstva i slično, što je oblikovalo njihova osećanja. ${ }^{45}$ Dovoljno je spomenuti da su taj put prešli predsednik Skupštine Ivan Ribar, ${ }^{46}$ zamenik ministra informacija Veljko Korać, načelnik odeljenja za štampu u tom ministarstvu ili šef novinske agencije Tanjug Dušan Vuksan.

Čehoslovački uticaji u jugoslovenskoj privredi bili su primetniji od poljskih. U izveštaju o radu poljsko-jugoslovenske Stalne komisije za ekonomska pitanja, poljska strana je priznala da „pažnju privlači veliki broj inženjera i tehničara koji su studirali u Čehoslovačkoj. Oni su prirodni ambasadori češke industrije i češke tehnike“. Propaganda obe zemlje je pompezno objavila trogodišnju razmenu 500 učenika tehničkih škola između Poljske i Jugoslavije, dok se u Čehoslovačkoj tada školovalo 3.000 osoba iz Jugoslavije. ${ }^{47}$ Jugosloveni su privrednu saradnju tretirali više kao privremenu - „pokazuje [Jugoslavija] aktivnost i veliko interesovanje na tim poljima - konstatovala je ambasada u Beogradu - na kojim očekuje da odmah postigne rezultate korisne za svoju zemlji [...]. Međutim, može se primetiti na jugoslovenskoj strani potcenjivanje dugoročne saradnje [podvukao činovnik ambasade]". Ovome treba dodati prezriv odnos poljske strane. U tehnološko-industrijskoj oblasti informativni rad je ocenjivan „veoma loše“; Poljsku su $\mathrm{u}$ tom pogledu distancirale druge zemlje regiona. Dokaz za to je bila činjenica da poljska strana nije potpisala nijedan ugovor (do 24. jula 1947, kako je predviđao trgovinski sporazum od 24. maja te godine), dok su Jugosloveni potpisali sve. Zamenik direktora Tehničkog odeljenja Ministarstva industrije i trgovine Henrik Gurecki ocenjuje da je uzrok tome nemar poljskih organa zaduženih za uvoz, a takođe, što je zanimljivije, „nesklonost naših delegata da putuju u zemlje sa nacionalizovanom trgovinom“. ${ }^{48}$

Uostalom, do sličnih problema je često dolazilo. Izvesnu površnost u poljsko-jugoslovenskim odnosima pokazuje i poseta poljske delegacije Beogradu 18-25. oktobra 1946. čiji je značaj bio, blago rečeno, minimalan. Tada nisu donete nikakve značajne odluke, a cela poseta je bila samo propagandni događaj. Po rečima Vlođimieža Kovalskog, „rezultati posete poljske delegacije Beogradu nisu mereni zbirom nekih konkretnih političkih sporazuma"; efektivnost politike treba meriti konkretnim rezultatima, a ne

${ }^{45}$ Ibid. Skupštine.

${ }^{46}$ Poljska ambasada ga je titulisala kao „predsednika“, mada je bio predsednik

7 AAN, WZ KC PPR, 295/XI-400, Sprawozdanie dla KC PPR z prac PolskoJugosłowiańskiej Komisji Stałej $w$ dniach od 18 lipca do 14 sierpnia 1947 r. w Belgradzie, 45; Slobodan Selinić, „Školovanje jugoslovenskih učenika u privredi u Poljskoj 1947/48“, Jugoslovensko-poljski odnosi u XX veku, zbornik radova, urednici Momčilo Pavlović, Andrzej Zaćminski, Dragomir Bondžić, (Beograd: Institut za savremenu istoriju, Institut za istoriju i međunarodne odnose, Bidgošć, 2015), 185-204.

${ }^{48}$ Ibid., 46. 
„pre svega veoma toplim dočekom poljske delegacije“. ${ }^{49}$ Razgovori vođeni „na opštepolitičkoj ravni odvijali su se efikasnije nego čisto trgovački razgovori“" ${ }^{50}$ - što bi moglo da svedoči o ograničenom obimu zajedničkih interesa. To se dešavalo i pored uverenja ministra Modzelevskog da „danas najbolje izgleda naš odnos prema Jugoslaviji [...], lako se nalazi zajednički jezik, jer šestogodišnja okupacija, zajedničko vođenje borbe i promene u državnom uređenju naših zemalja, kao i dalja opasnost koja proizlazi iz mogućnosti obnavljanja nemačke agresije - to sve nas zbližava“. ${ }^{51}$ Izostanak konkretnih rezultata upućuje na to da se kritički sagledaju navedena mišljenja.

Ukratko, može se zaključiti da su u poljsko-jugoslovenskim odnosima postojala dva nivoa. Prvi je činila zvanična i strateška sfera u kojoj su najvažniji bili osnovni interesi oba subjekta - uspostavljanje novog društveno-ekonomskog uređenja, utemeljivanje (antinemačkog) saveza slovenskih država i, što je najvažnije, posleratnih granica. Na tom polju saradnja obe države nije mogla da naiđe na ozbiljnije teškoće i zbog toga je relativno brzo nastupilo regulisanje dvostranih odnosa. Bitne razlike nastajale su na ideološkom polju, barem kod dela komunista, mada za njih nije bilo mesta $u$ zvaničnoj propagandi. U tadašnjoj stvarnosti, međutim, te razlike nisu mogle imati veliki uticaj na osnovna pitanja u poljsko-jugoslovenskim odnosima.

U svakom slučaju, moglo se primetiti interesovanje jugoslovenske strane za razvoj političke situacije u Poljskoj. Diplomatija te zemlje posvetila je veliku pažnju poziciji Poljske narodne partije (PSL), primećujući polovinom 1946. zaoštravanje odnosa između komunista i njihovih "dodataka“. PSL je opisana kao „legalna ekspozitura terorističke, fašističke [...] londonske vlade“. Labud Kusovac, izaslanik za štampu jugoslovenske ambasade, primetio je da u krilu PSL raste broj osoba nenaklonjenih liniji Stanislava Mikolajčika, a na „njeno čelo se ističe novinar Tadeuš Rek koji je prošle godine učestvovao u poseti poljskih novinara Jugoslaviji“. Za veoma verovatan je smatran "nastanak novog izbornog bloka [predviđen je bio raskol u PSL i stvaranje PSL Novo oslobođenje (naziv nije naveden $u$ dokumentu), šta se i odigralo 9. juna]. “52

Povećano interesovanje jugoslovenskih diplomata za situaciju u Poljskoj bilo je povezano sa referendumom „3 x DA“ planiranim za 30. jun.

${ }^{49}$ W. T. Kowalski, op. cit., 78.

${ }^{50}$ AAN, WZ KC PPR, 295/XI-400, Sprawozdanie z podróży służbowej do Jugosławii w dn. 627 X 1947 r., 82-83.

51 AMSZ, z. 15, w. 7, t. 66, Stenogram z wykładu wiceministra Modzelewskiego na temat sytuacji międzynarodowej $w$ dobie powojennej wygłoszonego w dniu 28 maja 1946 r., 23.

52 DA MSP, PA, Poljska, 1946, fasc. 72, dosije 12, sign. 6922, Izveštaj iz Varšave, Varšava, 2. 6. 1946, 1 (L XXII/251). 
U mišljenju Kusovca o strategiji PSL prema unutrašnjim pitanjima Poljske isprazno je tražiti ocene koje bi izlazile izvan konstatacije činjenice da Mikolajčikova partija ima „kulačko-reakcioni“ karakter.

Jugoslovenska diplomatija je sa razumevanjem prihvatala staljinističko tumačenje pitanja uspostavljanja (ili tačnije neuspostavljanja) diktature proletarijata prema sovjetskom modelu u Poljskoj da bi „u sadašnjim okolnostima“, prema potrebama, bila prilagođena situaciji u pojedinim zemljama. Navodno za „Poljake [nije precizirano koje] to je bilo iznenađenje“. ${ }^{53}$ Pozitivne rezultate referenduma, kao i kasnijih parlamentarnih „izbora“ 17. januara 1947. i izbor Bjeruta na položaj predsednika 5. februara od strane Sejma „društvo i vlada FNRJ su primili sa neskrivanim entuzijazmom". ${ }^{54}$ Ubrzanje procesa koji se zasnivao na osvajanju dominantne pozicije komunista u Poljskoj, u Jugoslaviji je pozdravljeno sa zadovoljstvom. Pozitivan stav nije zauziman samo prema pomenutim „glasanjima“, već i prema drugim koracima vlade - na primer, prema dobrim rezultatima obe amnestije. ${ }^{55}$ Novi jugoslovenski ambasador u Poljskoj (Rade Pribičević je u januaru 1947. Bjerutu predao akreditivno pismo) naglasio je ipak veliki značaj i silu oružane ilegale u Poljskoj pozivajući se na razgovore sa Stanislavom Radkjevičem, šefom Ministarstva javne bezbednosti. ${ }^{56}$

Jugoslovenska politika prema Poljskoj izgledala je takođe "budna“. Jedan od elemenata u kojima su se ocrtavale disproporcije u korist Poljske bilo je pitanje promovisanja kulture. Delikatno govoreći, uticaj jugoslovenske kulture tik posle rata bio je minimalan. U Beogradu je delovala poljskojugoslovenska Mešovita kulturna komisija, objavljivani su poljski književni radovi, drugi su bili u toku prevođenja; održavali su se nastupi poljskih umetnika. Zbog toga, MIP je počeo da se interesuje za mogućnost otvaranja, pod okriljem ambasadora FNRJ, analognog tela u Varšavi čiji bi cilj bio promovisanje jugoslovenske kulture i smanjivanje razlika u toj sferi. ${ }^{57}$ Stvaranje takve komisije je relativno brzo završeno već početkom februara 1947, mada su zbog političkih razloga rezultati njenog rada bili ograničeni. ${ }^{58}$

Kraj 1947. godine u kojoj se održavala konferencija komunističkih partija u Šklarskoj Porembi i naredna godina najavljivale su osnovni zaokret

${ }^{53}$ Teško je odrediti zašto bi Poljaci bili iznenađeni. Ibid., s. 3 (L-XXII/253).

54 AAN, WZ KC PPR, 295/XX-65, Raport za okres od 25147 do 15 II 47 r., nr 130/10/Tjn, z dn. 16 lutego 1947 r., 81.

${ }_{55}$ Ambasada je procenjivala da je 3.000 lica iskoristilo amnestiju. DA MSP, PA, Poljska, 1947, fasc. 100, dosije 4, sign. 46454, Telegram br. 220, 9. 4. 1947, b. p.

${ }^{56}$ Ibid., sign. 47598, Telegram br. 271, 25. 4. 1947, 1-2.

57 AAN, WZ KC PPR, 295/XX-65, Raport za okres od 25147 do 15 II 47, nr 130/10/Tjn, z dn. 16 lutego 1947 r., 79-80.

${ }^{58}$ Više informacija: DA MSP, PA, Poljska, 1947, fasc. 98, dosije 10, sign. 418826, Trećem regionalnom odeljenju, br. 901, 24. 8. 1947, b. p. Sve do izbijanja sukoba Komisija nije imala vremena da u potpunosti počne rad. 
ne toliko u poljsko-jugoslovenskim odnosima, koliko u relacijama Jugoslavije sa svim državama nastajućeg sovjetskog bloka. Rezultati pomenute konferencije još nisu izazvali sukob KPJ sa njenim sestrinskim partijama iz Srednjoistočne Evrope, na čelu sa Svesaveznom komunističkom partijom (boljševika). ${ }^{59}$ Ipak, posmatrajući iz današnje perspektive, već su se pojavili izvesni simptomi. Cilj ovog rada nije utvrđivanje detalja i geneze sukoba Tita i Staljina, ali se uz upućivanje čitalaca na niz detaljnijih obrada ove problematike ${ }^{60}$ može izneti izvesna teza. U tom smislu, ako prihvatimo kao opravdanu tvrdnju Mihala Ježija Zaharijasa da je taktika jugoslovenskih komunista, oslonjena na revolucionarne metode, dakle one koje vode do trenutnog preuzimanja vlasti, prema njima bila jedini ispravan put i istovremeno „kamuflirana“ kritika politike Kremlja prema državama Srednjoistočne Evrope ${ }^{61}$ nju treba u znatnoj meri primeniti i na Poljsku. Tu tezu potkrepljuju kritička mišljenja o situaciji u Poljskoj koja su se pojavila u drugoj polovini 1945. i nisu nestala do konferencije u Šklarskoj Porembi. Uvek su bila skrivena, $u$ drugom planu.

Svega nekoliko dana posle završetka konferencije, već 1. oktobra, Vende je imao (ne baš prijatan) razgovor sa Velebitom o realizaciji trgovinskog sporazuma od 24. maja. Velebit je izneo barem nekoliko primedbi poljskoj strani: zakašnjenja u sklapanju ugovora, kašnjenje isporuka koksa iz Poljske u Jugoslaviju i neregularno snabdevanje, zajedno sa optužbom da su transporti namenjeni njegovoj zemlji bili slati u druge. Vendeov odgovor je nosio tragove hladnoće: razlog kašnjenja sa ugovorima su „pre bile teškoće tehničke prirode i prvobitno dosta primetne razlike cena“. Taj aspekat je takođe trebalo da bude rešen „u najbližoj budućnosti“. Veći nesporazum se odnosio na pitanje koksa. Jugoslovenska strana je sugerisala neadekvatne isporuke, poljska pak - „da je Jugoslavija preuzela samo 50.545 tone od

${ }^{59}$ Iz razgovora savetnika poljske i jugoslovenske ambasade (Juškjevič - Fejč) u Moskvi 21. oktobra 1947: „On je zauzeo potpuno pozitivan stav“ prema odlukama konferencije. AMSZ, z. 15, w. 5, t. 37, Notatka służbowa z rozmowy przeprowadzonej przez radce Ambasady Aleksandra Juszkiewicza z radca Ambasady Jugosłowiańskiej w Moskwie Fejčem, $z$ dn. 8 X 1947 r., nr 332/3641 (Tj.), 43.

${ }^{60}$ Ivo Banac, With Stalin Against Tito: Cominformist Splits in Yugoslav Communism (Ithaca, London: Cornell University Press, 1988); Vojtěch Mastny, Stalin i zimna wojna (Warszawa: TRIO, 2006); Jeronim Perović, „The Tito-Stalin Split: A Reassessment in Light of New Evidence", Journal of Cold War Studies, vol. 9, no. 2 (Spring 2007), 32-63. Jugoslovenski stav, sa sadržinom pisama razmenjenih između partija, može se naći u: Pisma CK KPJ i pisma CK SKP(b) (Beograd: Borba, 1948). Inače, sukob je prinudio partijske vlasti na radikalnu promenu politike. U prvom redu da stabilizuju unutrašnju situaciju (likvidiranja tzv. informbirovaca), kasnije - da modifikuju politički sistem u Jugoslaviji posle promene spoljne politike zemlje, naročito suočavanja sa izolacijom od strane SSSR-a i država narodne demokratije.

${ }^{61}$ M. J. Zacharias, Komunizm, federacja...,. 99-103. 
82.700 tona koje je Poljska poslala“. ${ }^{62}$ Vende je zaključio da „u svetlu tih činjenica moraju da budu odbačene potpuno nejasne za mene vesti da je navodno poljska železnica namerno naredila da se na granici ne puštaju jugoslovenski vozovi koji zbog toga nedeljama čekaju na austrijskočehoslovačkoj granici“. Još oštrije se izrazio o transportima koksa u druge zemlje (umesto u Jugoslaviju) negirajući da se to dešava: „Treba pretpostaviti da su, prema meni dosta neverovatne, informacije trgovačkih predstavnika Jugoslavije koji borave u Katovicama [...] zasnovane na neistinitim informacijama i ne odgovaraju stvarnosti“. Zaključujući, Vende je sugerisao slanje "nekog energičnog stručnog predstavnika" koji bi preuzeo organizaciju razmene. Sve to je imalo mesto i pored uveravanja ambasadora Poljske da je Jugoslavija tretirana prioritetno „zbog poznatih obzira“. ${ }^{63}$

Objavljivanje Rezolucije Informbiroa 28. juna 1948. „O stanju u Komunističkoj partiji Jugoslavije" nije bilo istovetno sa trenutnim zaoštravanjem poljsko-jugoslovenskih odnosa, mada su simptomi toga postajali sve očevidniji. ${ }^{64}$ Bitan događaj te godine bio je Svetski kongres intelektualaca za odbranu mira u Vroclavu od 25. do 28. avgusta. Jugoslovenska strana je životno bila zainteresovana da učestvuje na kongresu, mada je već u etapi priprema delegacija došlo do nesporazuma sa poljskom stranom. Jugoslovenima se nije sviđalo to što su Poljaci, ne ostavljajući im nikakvu slobodu, poslali gotov spisak osoba pozvanih na kongres. Sten-Stoberski je odgovorio Ribnikaru (shodno uputstvu Ježija Borejše, predsednika organizacionog komiteta kongresa) da je prihvaćeno pravilo da se „pozivaju unapred predviđene osobe“ kako bi se izbegao dolazak „potpuno neadekvatnih" lica. Štaviše, organizatorima je zamerano što su suviše kasno poslali pozivnice „da bi jugoslovenskoj delegaciji onemogućili učestvovanje na kongresu“ ${ }^{65}$

Polovinom 1948. završio se period uspešne saradnje Poljske i Jugoslavije. Vođe Poljske radničke partije i poljska vlada odlučili su da gotovo direktno slede sovjetsku politiku prema KP Jugoslavije. To je značilo da su poljsko-jugoslovenski odnosi upali u duboku krizu koja je trajala do 1955.

${ }^{62}$ Nije objasnio šta se desilo sa preko 30.000 tona poslate sirovine.

${ }^{63}$ DA MSP, PA, Poljska, 1947, fasc. 100, dosije 18, sign. 420753, Pismo ambasadora $R P w$ Belgradzie do vice Ministra Spraw Zagranicznych FLRJ V. Velebita, Belgrad, 14. 10. 1947, 100/320-323 (1-4).

${ }^{64}$ Više, između ostalog: Marek Piotr Deszczyński, „Wykluczenie Komunistycznej Partii Jugosławii z Biura Informacyjnego Partii Komunistycznych i Robotniczych“, Studia $z$ Dziejów Rosji i Europy Środkowo-Wschodniej, t. 28 (1993), 109-131. Tito je na početku izbegavao da provocira Staljina na bilo koji način, trudio se da još revnosnije ostvaruje sovjetske ustavne uzore, na čelu sa kolektivizacijom poljoprivrede. SSSR je takođe mogao da računa na podršku Jugoslavije ili na forumu UN, ili barem na Dunavskoj konferenciji (30. jul - 18. avgust 1948) u Beogradu na kojoj je Jugoslavija podržala praktično sve zahteve SSSR-a. Up. M. J. Zacharias, Komunizm - federacja..., 105-109.

${ }^{65}$ AMSZ, z. 15, w. 11, t. 112, Raport nr 242/tjn/15, 30. 8. 1948 r., 16, itd. 
Jasno je da su samo politički razlozi određivali promene u poljskoj spoljnoj politici prema Beogradu. Bez obzira na to Poljska je ostala država koja je povezivala sovjetski blok i Jugoslaviju.

\section{IZVORI I LITERATURA}

- Archiwum Ministerstwa Spraw Zagranicznych w Waszawie (Arhiv Ministarstva spoljnih poslova u Varšavi), (AMSZ), fondovi Odeljenje za štampu i informacije i Kabinet Ministra

- Archiwum Akt Nowych (Arhiv novih dokumenata u Varšavi), (AAN), fond Inostrano odeljenje Centralnog komiteta Poljske radničke partije (WZ KC PPR)

- Diplomatski arhiv Ministarstva spoljnih poslova Republike Srbije (DA MSP), Politička arhiva (PA), Poljska, 1945-1948.

- Borba, Beograd (1945-1948)

- Duga, Beograd (1945)

- Głos Ludu, Warszawa (1945-1948)

- Banac, Ivo. With Stalin Against Tito: Cominformist Splits in Yugoslav Communism. Ithaca, London: Cornell University Press, 1988.

- Borodziej, Włodzimierz. Od Poczdamu do Szklarskiej Poręby. Polska w stosunkach międzynarodowych 1945-1947. London: Aneks, 1990.

- Deszczyński, Marek Piotr. „Wykluczenie Komunistycznej Partii Jugosławii z Biura Informacyjnego Partii Komunistycznych i Robotniczych“. Studia z Dziejów Rosji i Europy Środkowo-Wschodniej, t. 28 (1993), 109-131.

- Dobson Alan P., i Marsh Steve. US Foreign Policy since 1945. (The Making of the Contemporary World). London and New York: Rouledge, 2001.

- Dokumenti 1948, t. 1. Urednik Vladimir Dedijer. Beograd: Rad, 1980.

- Kersten, Krystyna. Narodziny systemu władzy. Polska 1943-1948. Poznań: Kantor Wydawniczy SAWW, 1990.

- Kowalski, Włodzimierz T. Polityka zagraniczna RP 1944-1947. Warszawa: Książka i Wiedza, 1971.

- Mastny, Vojtěch. Stalin i zimna wojna. Warszawa: TRIO, 2006.

- Perović, Jeronim. „The Tito-Stalin Split: A Reassessment in Light of New Evidence". Journal of Cold War Studies, vol. 9, no. 2 (Spring 2007), 32-63.

- Pisma CK KPJ i pisma CK SKP(b). Beograd: Borba, 1948.

- Rutyna, Zofia. Jugosławia na arenie międzynarodowej 1943-1948. Warszawa: Książka i Wiedza, 1981. 
- Selinić, Slobodan. Partija i diplomatija u Jugoslaviji 1945-1952. Beograd: Institut za noviju istoriju Srbije, 2013.

- Selinić, Slobodan. „Školovanje jugoslovenskih učenika u privredi u Poljskoj 1947/48". U: Jugoslovensko-poljski odnosi u XX veku, zbornik radova. Urednici Momčilo Pavlović, Andrzej Zaćminski, Dragomir Bondžić, 185204. Beograd: Institut za savremenu istoriju, Institut za istoriju i međunarodne odnose, Bidgošć, 2015.

- Zacharias, Michał Jerzy. Komunizm - federacja - nacjonalizmy. System polityczny w Jugosławii 1943-1991. Powstanie - przekształcenia - rozkład. Warszawa: Neriton, 2004.

- Zacharias, Michał Jerzy. „System stalinowski w Jugosławii 1944-1949“. Kwartalnik Historyczny, nr 3, (1992), 65-94.

- Zając Justyna, i Ryszard Zięba. Polska w stosunkach międzynarodowych 1945-1989. Toruń: Wydawnictwo Adam Marszałek, 2005.

Pavel Vavrišuk

POLISH-YUGOSLAV RELATIONS 1945-1948

\section{Summary}

After Second World War communist had seized power in Poland and Yugoslavia. However, in both states this process unfolded in a different way. In Poland, new regime was strongly supported by the Red Army and Soviet secret police (NKVD). In Yugoslavia, Josip Broz-Tito's partisans liberated country with allied support, but Soviet troops left Yugoslav borders after liberation of Belgrade. In these circumstances, political cooperation between Polish and Yugoslav communist governments and parties appeared as an important factor in post-war world. It became clear, that in priorities such as borders, internal policy, relaying on Soviet Union as a guarantee of security, will be similar. That was a background of model cooperation between states up till 1948. Polish-Yugoslav relations (1945-48) had been developing rapidly in comparison to other communist states in Central-East Europe (except Soviet Union) on cultural, economic or political field. However, Yugoslav communists unofficially showed lack of understanding of Polish political tactics, including delaying in implementation of stalinist's model in Poland. The absence of red star on the Polish flag, the presence of a cross on the highest Polish order's shape (Virtuti Militari), and above all the existence of other parties perplexed them. Despite that, these circumstances could not have had influence on main goal for Polish and Yugoslav government - to strengthen their power. 
KEYWORDS: Poland, Yugoslavia, international relations, PolishYugoslav relations

POLNISCH-JUGOSLAWISCHE BEZIEHUNGEN, 1945-1948

\section{Zusammenfassung}

Auf den Zweiten Weltkrieg folgte eine Machtübernahme der Kommunisten in den Ländern Polen und Jugoslawien. Diese wurde jedoch jeweils auf unterschiedliche Weise erreicht. In Polen wurde das neue Regime von den Truppen der Roten Armee sowie des Staatssicherheitsdienstes des Volkskommissariats für innere Angelegenheiten (NKVD) unterstützt. Josip Broz Titos Parteigänger befreiten Jugoslawien mit Hilfe der Alliierten, jedoch verließen die sowjetischen Truppen Jugoslawiens Grenzen nach der Befreiung von Belgrad. Unter diesen Umständen erschien die Kooperation zwischen dem kommunistischen Regierungen Polens und Jugoslawiens als einer der wichtigsten Ziele der beiden Länder in der Nachkriegsära. Es wurde deutlich, dass sich die Prioritäten wie Grenzen, Innenpolitik und Beziehungen zur Sowjetunion als Sicherheitsgarant beider Staaten ähnelten was zur Grundlage der erfolgreichen Kooperation bis 1948 wurde. Die Beziehung zwischen Polen und Jugoslawien entwickelte sich rapide in den Bereichen Wirtschaft, Politik und Kultur zwischen 1945 und 1948. Dieser Lauf ist für die damalige Zeit eher ungewöhnlich, das Gros der anderen kommunistischen Staaten, mit Ausnahme der Sowjetunion, pflegt solch enge und freundschaftliche Beziehung nicht. Die politischen Taktiken der Polen konnten allerdings nicht vollständig von den Jugoslawen nachvollzogen werden, wodurch es zu einer Verzögerung bei der Implementierung jener in Jugoslawien kam. Es zeigte sich Unverständnis auf Seiten der Jugoslawen für die Abwesenheit des kommunistischen roten Sterns auf Polens rot-weißer Flagge, Unverständnis dafür dass der höchste polnische Kriegsorden (Order Wojenny Virtuti Militari) die Form eines Kreuzes hatte, während dieses Symbol eigentlich ein Teil der Kirche war, welche das kommunistische Regime zu unterdrücken versuchte sowie Unverständnis dafür, dass die kommunistische Partei nicht die ganze Regierungsmacht innehatte, da sie nicht die einzige regierende Partei darstellte. Trotz allen Unterschieden hatten die Regierungen beiden Länder jedoch ein einheitliches Ziel: die Stärkung ihrer eigenen Machtposition.

SCHLÜSSELWÖRTER: Polen, Jugoslawien, internationale Beziehungen, Polnisch-Jugoslawische Beziehungen 